\title{
The Political Economy of Europe's Incomplete Single Market
}

Progress in European market integration over the past two decades has come at the expense of growing flexibility, or differentiation, in the laws that govern the Single Market (SM) as well as the way that these laws are implemented. This volume examines how the completion of the SM has been held back in the varied implementation of European Union competition policy, variation in national policies on services, corporate law, telecommunications, energy, taxation, and gambling, and the EU's uneven transportation network. These sectors and issue-areas form the frontier at which the main political struggles over the future shape of the SM have taken place in the past decade. Broadly, progress in economic integration in the EU has been complicated by the need to reconcile perfections to the SM with the global competitiveness of European producers, and efficiency gains with ideational and normative concerns. In services, there is a clash between deregulation and social policy. Financial integration has had to reconcile different institutionalized views among the member states about the place of finance in the economy and society. The SM notion supposedly entails a concrete set of substantive policy commitments that form the basis of the 'ever closer union'. However, increasing differentiation in the SM undermines the identification of the EU's core constitutional commitments.

This book was originally published as a special issue of the Journal of European Public Policy.

David Howarth is a Jean Monnet Chair and Senior Lecturer in Politics and International Relations at the University of Edinburgh. He is the author or co-author of three books including The ECB: the New European Leviathan, Palgrave, 2005, revised second and numerous journal articles and book chapters on Economic and Monetary Union, the political economy of European integration and comparative political economy.

Tal Sadeh is a Senior Lecturer in Political Science at Tel Aviv University. 


\section{Journal of European Public Policy Series}

Series Editor: Jeremy Richardson is a Professor at Nuffield College, Oxford University

This series seeks to bring together some of the finest edited works on European Public Policy. Reprinting from Special Issues of the 'Journal of European Public Policy,' the focus is on using a wide range of social sciences approaches, both qualitative and quantitative, to gain a comprehensive and definitive understanding of Public Policy in Europe.

Towards a Federal Europe

Edited by Alexander H. Trechsel

The Disparity of European Integration

Edited by Tanja A. Börzel

Cross-National Policy Convergence:

Causes Concepts and Empirical Findings

Edited by Christoph Knill

\section{Civilian or Military Power?}

European Foreign Policy in Perspective

Edited by Helene Sjursen

The European Union and New Trade Politics

Edited by John Peterson and Alasdair R. Young

\section{Comparative Studies of Policy} Agendas

Edited by Frank R. Baumgartner, Christoffer Green-Pedersen and Bryan D. Jones
The Constitutionalization of the European Union

Edited by Berthold Rittberger and Frank Schimmelfenig

Empirical and Theoretical Studies in EU Lobbying

Edited by David Coen

Mutual Recognition as a New Mode of Governance

Edited by Susanne K. Schmidt

France and the European Union

Edited by Emiliano Grossman

Immigration and Integration Policy in Europe

Edited by Tim Bale

Reforming the European Commission

Edited by Michael W. Bauer 
International Influence Beyond Conditionality

Postcommunist Europe after EU enlargement

Edited by Rachel A. Epstein and Ulrich Sedelmeier

The Role of Political Parties in the European Union

Edited by Björn Lindberg, Anne Rasmussen and Andreas Warntjen

\section{EU External Governance}

Projecting EU Rules beyond Membership

Edited by Sandra Lavenex and Frank Schimmelfennig

EMU and Political Science

What Have We Learned?

Edited by Henrik Enderlein and Amy Verdun
Learning and Governance in the $\mathbf{E U}$ Policy Making Process

Edited by Anthony R. Zito

Political Representation and EU Governance

Edited by Peter Mair and Jacques Thomassen

Europe and the Management of Globalization

Edited by Wade Jacoby and Sophie Meunier

Negotiation Theory and the EU The State of the Art

Edited by Andreas Dür, Gemma Mateo and Daniel C. Thomas

The Political Economy of Europe's Incomplete Single Market

Edited by David Howarth and Tal Sadeh 



\section{The Political Economy of Europe's Incomplete Single Market}

Edited by

David Howarth and Tal Sadeh 
First published 2012

by Routledge

2 Park Square, Milton Park, Abingdon, Oxon, OX14 4RN

Simultaneously published in the USA and Canada

by Routledge

711 Third Avenue, New York, NY 10017

Routledge is an imprint of the Taylor \& Francis Group, an informa business

(C) 2012 Taylor \& Francis

This book is a reproduction of the Journal of European Public Policy, vol. 17, issue 7. The Publisher requests to those authors who may be citing this book to state, also, the bibliographical details of the special issue on which the book was based.

All rights reserved. No part of this book may be reprinted or reproduced or utilised in any form or by any electronic, mechanical, or other means, now known or hereafter invented, including photocopying and recording, or in any information storage or retrieval system, without permission in writing from the publishers.

Trademark notice: Product or corporate names may be trademarks or registered trademarks, and are used only for identification and explanation without intent to infringe.

British Library Cataloguing in Publication Data

A catalogue record for this book is available from the British Library

ISBN13: 978-0-415-67768-4

Typeset in Times New Roman

by Routledge

\section{Disclaimer}

The publisher would like to make readers aware that the chapters in this book are referred to as articles as they had been in the special issue. The publisher accepts responsibility for any inconsistencies that may have arisen in the course of preparing this volume for print. 


\section{Contents}

Notes on contributors $\quad$ ix

1. Preface

David Howarth and Tal Sadeh

2. The ever incomplete single market: differentiation and the evolving frontier of integration

David Howarth and Tal Sadeh

3. Single market, global competition: regulating the European market in a global economy

Mitchell P. Smith

4. Discretion by the rules: European state aid policy and the 1999 Procedural Regulation

Nikolaos Zahariadis

5. Are you being served? Europeanizing and re-regulating the single market in services

Georg Menz

6. The political economy of telecoms and electricity internationalization in the single market Judith Clifton, Daniel Díaz-Fuentes and Julio Revuelta

7. Completing the single market in financial services: the politics of competing advocacy coalitions

Lucia Quaglia

8. Stakes and states: gambling and the single market

Vincent Della Sala

9. Let's get physical: the European Commission and cultivated spillover in completing the single market's transport infrastructure Paul Stephenson 


\section{CONTENTS}

10. Does Europeanization lead to policy convergence? The role of the Single Market in shaping national tax policies

Achim Kemmerling

Index 


\section{Notes on contributors}

Judith Clifton is Senior Lecturer, Department of Economics, University of Cantabria, Spain.

Daniel Díaz-Fuentes is Professor, Department of Economics, University of Cantabria, Spain.

David Howarth is a Jean Monnet Chair and Senior Lecturer in Politics and International Relations, School of Social and Political Science, University of Edinburgh, UK.

Achim Kemmerling is Associate Professor at the Department of Public Policy, Central European University Budapest, Hungary.

Georg Menz is Reader in Political Economy at Goldsmiths College, London.

Lucia Quaglia is Senior Lecturer in Politics and Contemporary European Studies at the University of Sussex, UK.

Julio Revuelta is Assistant Lecturer, Department of Economics, University of Cantabria, Spain.

Tal Sadeh is a Senior Lecturer in Political Science at the University of Tel Aviv, Israel.

Vincent Della Sala is Associate Professor of Political Science at the University of Trento, Italy, and Adjunct Professor at the Bologna Center of the Johns Hopkins' School of Advanced International Studies, USA.

Mitchell P. Smith is Associate Professor of Political Science and International and Area Studies and Co-director of the European Union Center at the University of Oklahoma, USA.

Paul J. Stephenson is Assistant Professor in European Studies at the Department of Political Science, Maastricht University, The Netherlands.

Nikolaos Zahariadis is Professor of Political Science at the University of Alabama at Birmingham, USA. 